\title{
LEGAL RESTRICTIONS ON MEDICAL INTERVENTION DURING OPERATION ON FEMALE GENITALIA FOR NON-MEDICAL PURPOSES
}

DOI: $10.36740 /$ WLek202012234

\author{
Volodymyr I. Tiutiuhin, Anton 0. Baida, Viktoriia V. Bazeliuk \\ YAROSLAV MUDRYI NATIONAL LAW UNIVERSITY, KHARKIV, UKRAINE.
}

\begin{abstract}
The aim: To identify problems associated with non-medical genital surgery and establish the limits of acceptable medical intervention in such operations.

Materials and methods: The study is based on a theoretical basis, which includes reviews of legislation, reports from non-governmental organizations, and is based on empirical data: decisions of the European Court of Human Rights, international regulations, statistics of the World Health Organization. Systemic and structural, comparative legal and functional methods, systematization, analysis and synthesis were decisive in the research process.

Conclusions: "Female genital mutilation" or "female circumcision" is essentially a separate type of bodily injury that is caused intentionally in accordance with various social domestic and religious traditions and beliefs of certain emigrant ethnical religious communities. Such actions are a form of discrimination and violation of women's rights on the basis of gender, as well as a form of child abuse, as the vast majority of such operations are carried out on girls under 12 years of age. Medical intervention in case of operations on female genitalia, including for non-therapeutic purposes, can be considered legitimate only with the informed consent of the patient and on conditions that the level of danger to human health from such intervention corresponds to the concept of personal autonomy, that is, it does not require direct state intervention for the reasons of urgent social necessity.
\end{abstract}

KEY WORDS: consent to harm, female genital mutilation, female circumcision, bodily injury, gender discrimination

Wiad Lek. 2020;73(12 p. II):2909-2914

\section{INTRODUCTION}

Despite the fact that most female circumcision operations are performed in Africa and the Middle East countries, female circumcision has reached the level of an international problem that exists in over 30 countries. Female circumcision is also performed in Latin America, Asia, as well as in Australia and NewZealand. Although this practice is not common in Europe, migrants living in Western Europe often carry out these operations. The causes of female genital mutilation depend on the level of development of society, region, family, their culture and traditions. The most common reason for such a phenomenon is the social norm in the corresponding environment, where women are simply afraid of being rejected by society, because there such an operation is considered a commonplace.

Thus, this problem does not really go to the distant past, but it exists in the present, because any modern country can face it. That is why the World Health Organization is currently actively fighting against the practice of female circumcision.

One of the indisputable facts of recognizing the existence of the problem of female circumcision in the world was the adoption on 11 May 2011 of the Council of Europe Convention on Preventing and Combating Violence against Women and Domestic Violence (hereinafter referred to as the Istanbul Convention).

According to Art. 38 of the Istanbul Convention, the Parties shall take the necessary legislative or other measures to ensure the criminalization of such forms of intentional conduct as: a) removal, infibulation or making any other injury in whole or in a part of the labia majora, labia minora or clitoris; b) forcing or inducement of a woman to be subjected to the acts listed in subparagraph (a); c) incitement, forcing a girl to be subjected to the acts listed in subparagraph (a), or inclining her to do so [1].

\section{THE AIM}

The aim of this article is: a) to determine the state of legal regulation of the operations on the female genitalia for non-medical purposes; b) establishing the limits of permissible medical intervention in the case of such operations.

\section{MATERIALS AND METHODS}

The theoretical and empirical basis of the study includes the reviews of national and foreign legislation, doctrinal positions, decisions of the European Court of Human Rights, regulations of Italy, Sweden and other Parties to the Istanbul Convention, statistics of the World Health Organization. International legal acts of the United Nations and the World Health Organization are also used in the work.

In particular, regarding the legality of female circumcision and permissible medical intervention, the provisions 
of the Convention for the Protection of Human Rights and Dignity of the Human Being with regard to the Application of Biology and Medicine were studied as well as the Convention on Human Rights and Biomedicine; Declaration of Lisbon on the Rights of the Patient; Council of Europe Convention on "Preventing and Combating Violence against Women and Domestic Violence"; Convention for the Protection of Human Rights and Fundamental Freedoms; the case of the European Court of Human Rights LASKEY AND OTHERS v. THE UNITED KINGDOM; 20 cases in which a reasonable suspicion was raised of mutilation of female genitalia (female circumcision) under the Criminal law of the EU (cases were registered in the countries of the European Union, in particular in Germany, France (most cases), Italy, Spain, Sweden, Norway). The statistics of the countries where the pernicious practice of female genital mutilation is traditionally the most common - Egypt (95.8\%), Djibouti (93.1\%), Guinea (95.6\%), Mali (91.6\%), Somalia (97, 9\%), Sierra Leone (94\%) and Sudan (North Sudan - 80\% of respondents).

The methodological basis of the work is based on general scientific and special research methods. The dialectical method is used to define the terms "removal", "infibulation", "any other injury", "female genital mutilation", the statistical method is used in the analysis of statistical data, the comparative - in the study of the experience of countries such as Ukraine, Italy, Sweden and other countries, Parties to the Istanbul Convention. Comparative method and generalization method are used in the study of the legislation of some countries and the decisions of the European Court of Human Rights. Through the use of logical and historical methods, a deeper understanding of the essence of the problem is achieved, and it is possible to provide sound suggestions and recommendations for their solution.

\section{REVIEW AND DISCUSSION}

According to Art. 2 of the Convention for the Protection of Human Rights and Fundamental Freedoms, human life, health are the highest social values and are under special protection of the state. The current Criminal Code of Ukraine (hereinafter the Criminal Code) prohibits causing harm to the life and health of another person under a threat of criminal liability. Such a prohibition is established by a number of norms provided by Articles 115-128 of the Criminal Code. In addition, the current criminal legislation of Ukraine contains provisions for the protection of human life and health from improper medical practice (medical activity), for which criminal liability is established in Articles 131, 132, 134, 138-144 of the Criminal Code.

The criminal acts provided by these norms are within the general concept "crimes in the field of medical activity". A common feature of these norms (both "general" and "special" in the field of medical activity) is that they provide for the liability for unlawful (intentional or negligent) harm to life and health of another person. Accordingly, harmful acts against oneself or others, with the informed consent of the latter or their legal representatives, may in certain circumstances, be considered non-criminal or even lawful interference in the life and health of a person.

A separate problem is the commission of certain acts by medical workers in the absence of medical necessity. In the latter case, a clear example is the practice of female circumcision. In accordance with the judicial practice of the European Court of Human Rights (hereinafter ECHR) on the protection of patients from unwarranted medical intervention (examination and treatment) [10] under Articles 2, 8 and 14 of the Convention for the Protection of Human Rights and Fundamental Freedoms (hereinafter the Convention for the Protection of Human Rights) and a number of international documents on bioethics [2; $3]$, medical staff is prohibited from performing medical intervention without the informed consent of the patient, as well as from conducting such operations for non-medical purposes, if they cause harm to the patient's health. However, except for the situations where there is a more or less clear regulation of the legality (or illegality) of their conduct (in particular, abortion, euthanasia, etc.), a systematic approach to determining the admissibility of medical intervention in the European practice is still missing.

The Istanbul Convention [1], which aims to prevent and eliminate this phenomenon, also provides an international mechanism for monitoring the implementation of its provisions at the national level. In accordance with this Convention, amendments were made to the Criminal Code of Ukraine, in particular to Art. 121 of the Criminal Code of Ukraine. The concept of grievous bodily harm was expanded by supplementing it with such a feature as genital mutilation. According to Art. 38 of the Istanbul Convention, States - Parties shall take the necessary legislative and other measures to ensure that the above forms of intentional female genital mutilation are criminalized $[1 ; 16]$.

These operations are performed without medical and / or cosmetic indications for their conducting, which differs from the permitted forms of medical intervention and plastic (cosmetic) operations on the genitals [6, p. 2].

It should also be noted that there is no single comprehensive approach to defining the concept of consent to such an operation, which leads to the fact that, according to the World Health Organization (hereinafter WHO), medical workers actually perform about $18 \%$ of operations of female genitalia mutilation [11].

One of the reasons for this situation is the lack in the legislation of the States - Parties to the Istanbul Convention, of a clear prohibition to conduct such operations, regardless of the consent of an informed adult person. The analysis of the criminal law of 28 European countries, 21 of which have already ratified the Istanbul Convention [12], showed that: 13 countries (Austria, Belgium, Croatia, Denmark, Estonia, Germany, Italy, Norway, Portugal, Great Britain, Romania, Sweden, Switzerland) have provided in their national legislation a separate (special) rule on liability for female genital mutilation. Moreover, 10 of these countries have established such responsibility regardless of the woman's consent to such an operation. At the same time, 15 countries did not provide for a separate rule on female 
genital mutilation and did not amend their domestic (national) legislation, and therefore female genital mutilation is punishable by their laws in general as bodily injuries of some severity [13].

The Criminal Code of Ukraine provides for a gender-neutral norm, which establishes the liability for mutilation of both female and male genitalia. But despite the fact that the Criminal Code of Ukraine contains such a feature as genital mutilation, it remains unclear what exactly should be understood by such acts and how to be in a situation when this female circumcision is performed by a medical worker in relation to an adult with her informed consent for such an intervention. Can such acts be considered as a circumstance that excludes the criminality of the act, and the consent of the victim to conduct such an operation can be recognized as lawful?

This issue is particularly relevant against the background of the fact that a number of local regulations of other countries, Parties to the Istanbul Convention, clearly state that these operations are conducted for non-medical (non-therapeutic) purposes and are aimed at depriving the organs of proper sexual function (Article 538bis of the Italian Criminal Code). [7, p. 20].

In accordance with the features given in the above international acts and the WHO guidelines, the term "female genital mutilation" can be defined as all procedures involving partial or complete removal of the external genitalia for non-medical purposes [9,p.4]. Thus, the above four types of female genital mutilation in their content are carried out for non-medical purposes. The indication of the non-medical purpose of this operation is also because the fact that for a long time (from the mid-nineteenth century to the 50s of the twentieth century) female circumcision (including clitoridectomy) was used as a method of "treating female weaknesses", including nymphomania, depression, hysteria, etc. [14].

International law recognizes female genital mutilation as a gross form of discrimination and a significant violation of women's rights. This tradition is typical (99\%) for the western, eastern and north-eastern regions of the African continent, as well as for some countries in Asia, the Middle East and among the closed communities of North American immigrants and Europe.

The issue of banning this practice in Europe has arisen due to a significant increase in the number of representatives of certain communities in the European Union, especially in Germany and France. Such actions are a consequence of religious or ethnical and religious traditions and beliefs and are carried out as a part of the rite of coming of age, preparation for marriage, adult life, preservation of female virginity.

In order to implement the above-mentioned international agreements, the countries of the European Union have adopted a number of local regulations on the prevention and counteraction to the facts of female genital mutilation (female circumcision). In particular, the Law on Combating Female Circumcision was adopted in Sweden in 1982 (Law № 1982:316). At the same time, as of 2009, according to the police, about twenty cases of reasonable suspicion were identified, two of which were the subject of court proceedings. But, as researchers note, cases in this category are characterized by a fairly high degree of latency [6, p. 5-6].

Cases of female genital mutilation in accordance with the court practice of these countries can be divided into two groups, namely:

a) cases of female circumcision in its pure form (socalled "typical" cases of female circumcision [15, p. 102], in which the intent and mainly a special purpose - religious or traditional, including marriage practices) are taken as the criteria;

b) cases of female genital mutilation, which can be attributed to this group only conditionally, as they can be recognized as such only in terms of consequences (socalled "atypical" cases of female circumcision) [15, p. 99].

The fact is that the Istanbul Convention does not differentiate between the acts committed in connection with religious or traditional practices and others, including negligent acts, which are the result from, for example, medical error, negligence, etc.

The analysis of the content of Art. 121 of the Criminal Code of Ukraine also allows us to conclude that, firstly, there is no clear definition of what exactly should be meant by genital mutilation and, secondly, how exactly this feature corresponds to other signs of serious injuries, the types of which are listed in Art. 121 of the Criminal Code.

I. Mytrofanov, I. Lysenko, K. Hryn, M. Ryabushko [16] reasonably paid attention to these problems. Researchers in other countries also pay attention to this issue. For example, Inger-Lise Lien analyzed over 50 cases in the last 10 years in Norway (2017 study), none of which had been charged [8]. Among the main reasons for this situation, the author points (i) lack of medical proof; (ii) determining the timing of the scar; (iii) the parents' denial of knowing about the procedure; (iv) lack of witnesses in Norway that can connect parents to the crime; (v) children who cannot remember or know if they were cut or not as the procedure was done when they were babies; (vi) lack of competence by those who report cases, generating many false alarms such as labia adhesion, and (vii) the principle of 'in dubio pro reo' (when in doubt, find for the accused) [8].

It should be noted that the legislation of some countries also does not establish a legal difference (distinction) between these acts. Thus, in accordance with Part 1 of Art. 538biz of the Criminal Code of Italy, criminally punishable are any actions that led to the removal of certain parts of female genitalia and resulted in a physical or mental disorder (without specifying the degree of such disorder). Similar provisions are contained in the criminal law of other EU countries that are the Parties to the Istanbul Convention. That is, under the laws of these countries, the consequences, which actually are in a specific form of grievous bodily harm, make a separate rule, and liability for their infliction arises regardless of the specific purpose or intention, i.e. without taking into account the nature of this operation as such. It should also be noted that criminally punishable under the Criminal Code of the States - Parties to the Istanbul 
Convention are any actions that have led to female genital mutilation in accordance with the above four types. Such actions are criminally punishable regardless of the age of a person in respect of whom the operation was performed, i.e. actions committed at the request (with the consent) of an able-bodied adult are punishable if they correspond to the four types of genital mutilation. As for such actions committed by the victim against herself, they do not entail criminal liability, but may be the grounds for proceedings under this rule of criminal law, if it is established the fact of aiding, abetting, inciting or otherwise instigating this girl for the procedure of female genital mutilation.

The stated above gives grounds to draw the following conclusions: - cases (criminal proceedings) concerning female genital mutilation are characterized by a high degree of latency; - the number of cases (criminal proceedings) brought to a conviction is a relatively small percentage of the total number of cases (criminal proceedings) involving female genital mutilation; - persons found guilty of committing these acts, in the vast majority of cases belong to the ethnic groups in which the commission of such acts is a traditional practice; - the legislation of the EU Member States generally does not contain a clear distinction between female genital mutilation and other actions that result in injury to female genitalia (in particular, due to improper medical practice).

In view of the above, it can be argued that in the vast majority of cases, the legislation of the States - Parties to the Istanbul Convention, recognizes such operations as criminal, regardless of the consent of a victim. That is, the fact of a victim's consent to such an operation is not considered as creating a circumstance that excludes the criminality of the act. However, none of the normative acts that have been analyzed contain a clear indication that a victim's consent to conduct such an operation against her does not exclude the criminal liability of a person who carried it out.

In view of the above, a question arises that is relevant for the current criminal legislation of Ukraine - is voluntary and informed consent of an adult important for making an operation of female circumcision and what is the solution to the issue of liability for the operation of female circumcision? This issue is of particular importance because, unlike the legislation of other States - Parties of the Istanbul Convention, the criminal legislation of Ukraine does not contain a separate (special) rule that would establish responsibility for these actions. It is also not taken into account that such operations can be carried out for any purpose, including those which are the result of improper medical intervention, medical error, etc., which somewhat offsets the tasks set before the States - Parties of the Istanbul Convention.

The issue of consent to medical intervention in the general sense is also urgent. In other words, it is important to find the limits according to which medical intervention, which, although not life-threatening (with life-threatening intervention, including actions such as euthanasia, it is more or less clear), but is unacceptable from a moral and ethical point of view, culture, traditions, customs, etc. Does such intervention require a ban, including through the means of criminal influence by the state?
In this regard, it is important to refer to the analysis of Art. 8 of the Convention for the Protection of Human Rights and Fundamental Freedoms, in particular, the right to respect for private and family life. According to the content of this article, everyone has the right to respect for his/her private and family life, his/her home and correspondence. Public authorities may not interfere in the exercise of this right, except for the cases where such interference is carried out in accordance with the law and is necessary in a democratic society in the interests of national and public security or economic well-being of the country, to prevent riots or crimes, to protect health or morality or to protect the rights and freedoms of others [4]. Despite the numerous cases of the ECHR, including in the field of bioethics, there is no clear answer to the above question. It is also unclear what mechanism is involved in the exercise of this right to medical intervention.

To resolve this issue, we should refer to the case of $L A S$ KEY AND OTHERS v. THE UNITED KINGDOM [5]. The applicants in the present case considered that their accusation of violence and bodily harm in the course of concerted sadomasochistic activities between adults was the State interference in their private lives and a violation of Art. 8 of the Convention. In particular, it was about the admissibility of state intervention in the voluntary infliction of harm to each other and the extent to which the consent of the victim is illegal and does not exclude the liability of the person who caused the injury.

According to the decision in this case, several clear theses were formulated. Thus, the court found that the injuries which had been or could have been caused by the applicants' activities were substantial in nature and that the conduct in question was extreme in all respects. Therefore, public authorities acted within their competence to protect their citizens from the real risk of serious physical harm or serious injury. Considering this, the following was stated:

1) the notion of the need for intervention implies that it corresponds to an urgent social need and, in particular, is proportional to the legitimate aim;

2) determining the level of harm to be allowed by law in the situations where the victim agrees to inflict it is a matter for the State concerned, as it relates, on the one hand, to public health considerations and the general deterrent effect of criminal law, and on the other hand, it relates to the autonomy of the individual [5].

According to Art. 121 of the Criminal Code of Ukraine mutilation of genitals is a serious injury. Thus, in terms of the severity of the damage, the infliction of such consequences corresponds to the notions "serious damage to health" and "serious injuries, mutilation" specified in the ECHR's decision.

In view of the above, we should agree with the solution of this problem proposed by V.I. Antipov, who considers the voluntary consent of the adult victim to inflict bodily harm on him/her necessary to recognize a circumstance that does not exclude liability, but only mitigates punishment (Part 2 Article 66 of the Criminal Code of Ukraine), so that such punishment is recognized as necessary, appropriate, 
sufficient and permissible state interference in private life in a democratic society. On conditions of proportionality of the sentence imposed, this will significantly reduce the possibility of the ECHR's satisfaction of the complaints of violations of paragraph 2 of Art. 8 of the Convention [17, p. 295].

Thus, according to the judicial practice of the ECHR, consent to harm is not unlimited, even in cases where the latter is not explicitly prohibited in its content and corresponds to understandable and established in society (or in some part of it) moral and ethical, religious beliefs and so on.

\section{CONCLUSIONS}

The stated above allows us to conclude that medical intervention, including that one conducted for non-therapeutic purposes, can be considered legitimate only if the level of danger to health from such intervention corresponds to the concept of autonomy of the individual, therefore, does not require direct state intervention for the reasons of urgent social necessity. Female circumcision clearly does not correspond to the concept of autonomy of an individual as such actions have serious consequences. That is why, the conduct of this operation by a medical worker, even in a medical institution and with the informed consent of the injured adult, cannot be considered as a circumstance that excludes the criminality of the act.

Taking into account the above, the following conclusions can be formulated: 1) the term "female genital mutilation" or "female circumcision" is well established in international practice, and the commission of such acts is mandatory for criminalization in accordance with the Istanbul Convention; 2) these criminal acts are essentially a separate type of bodily injury, which are caused intentionally in accordance with different social domestic and religious traditions and beliefs of certain emigrants' ethnical and religious communities and which are represented in different percentages in the European Union; 3 ) such acts are one of the forms of discrimination and violation of women's rights on the basis of gender and abuse of children, as the vast majority of operations are conducted against the girls under 12 years of age; 4 ) international instruments oblige to criminalize these acts separately, regardless of whether they are provided for in the relevant provisions of national law as a certain type of bodily injury; 5) in accordance with the current legislation of the States - Parties of the Istanbul Convention, all acts that have led to the consequences of four types and / or certain mental or physical harm are recognized as criminally punishable; 6 ) the current criminal legislation of Ukraine in Art. 121 of the Criminal Code enshrines such a feature as genital mutilation, with no indication of its non-medical (non-therapeutic) purpose, and the legislative wording allows to recognize a person of both female and male sex as a victim of this crime; 7) according to the practice of the ECHR, consent to harm is not unlimited even in cases where the latter is not explicitly prohibited in its content and corresponds to understand- able and established in society (or in any part of it) moral and ethical, religious beliefs, etc.; 8) medical intervention, including that one conducted for non-medical (non-therapeutic) purposes, may be recognized as lawful only if the level of health risk from such intervention corresponds to the concept of autonomy of an individual and therefore does not require direct state intervention for the reasons of urgent social necessity.

\section{REFERENCES}

1. Council of Europe Convention on preventing and combating violence against women and domestic violence (Istanbul, 11.V.2011). Available from: https://www.coe.int/ru/web/conventions/full-list/-/ conventions/rms/090000168008482e [reviewed 2020.08.01]

2. Convention for the Protection of Human Rights and Dignity of the Human Being with regard to the Application of Biology and Medicine: Convention on Human Rights and Biomedicine (Oviedo, 4.IV.1997). Available from: https://rm.coe.int/168007cf98 [reviewed 2020.08.18].

3. WMA Declaration of Lisbon on the rights of the patient (Lisbon, 01.10.1981). Available from: https://www.wma.net/wp-content/ uploads/2005/09/Declaration-of-Lisbon-2005.pdf [reviewed 2020.08.01].

4. Convention for the Protection of Human Rights and Fundamental Freedoms (European Convention on Human Rights). Rome, 04.XI.1950. Available from: https://www.echr.coe.int/Documents/Convention_ ENG.pdf [reviewed 2020.08.18].

5. Case of Laskey And Others v. The United Kingdom. Available from: http://hudoc.echr.coe.int/eng?i=001-58021 [reviewed 2020.08.10].

6. Sara Johnsdotter. Malmö University. January 2009. The FGM Legislation Implemented: Experiences from Sweden. Available from: http://www. uv.es/cefd/17/Johnsdotter.pdf. [reviewed 2020.08.10].

7. Sara Johnsdotter, Ruth M. Mestre i Mestre. Female Genital Mutilation in Europe: An analysis of court cases. Luxembourg, Publication Office of the European Union, 2015. Available from: http://muep. mau.se/bitstream/handle/2043/20517/JohnsdotterMestre2015. pdf?sequence $=2 \&$ isAllowed $=y$ [reviewed 2020.08.10].

8. Inger-Lise Lien. Prosecution of the Offence of Female Genital Mutilation/ Cutting in Norway. International Journal of Law, Policy and the Family. 2017; 31(2):191-206. doi:10.1093/lawfam/ebx003.

9. Eliminating female genital mutilation: an interagency statement UNAIDS, UNDP, UNECA, UNESCO, UNFPA, UNHCHR, UNHCR, UNICEF, UNIFEM. WHO. World Health Organization 2008. 40 p. Available from: https://www.unicef.org/french/media/files/Interagency_Statement_ on_Eliminating_FGM.pdf [reviewed 2020.08.18].

10. Otchet o provedenii issledovaniya. Problemyi bioetiki v svete sudebnoy praktiki Evropeyskogo Suda po pravam cheloveka [Report on the study. Problems of bioethics in the light of the jurisprudence of the European Court of Human Rights]. Available from: https://rm.coe.int/ case-law-2017/1680736451. [reviewed 2020.08.18] ( Ru).

11. Pochemu v 00N protestuyut protiv «zhenskogo obrezaniya»? [Why are UN protests against "female circumcision"?] Novosti 00N. Available from: https://news.un.org/ru/audio/2014/07/1023811 [reviewed 2020.08.18] ( Ru).

12. Chart of signatures and ratifications of Treaty 210. Council of Europe Convention on preventing and combating violence against women and domestic violence. Available from: https://www.coe.int/en/web/ conventions/full-list/-/conventions/\%20treaty/210/signatures?p_ auth $=$ fAuyuej0 [reviewed 2020.08.19]. 
13. Compendium of International and National Legal Frameworks on Female Genital Mutilation. Second edition, February 2018. The World Bank Group. Washington DC. 143 p.; Penal Code of Estonia. Available from: http://documents.worldbank.org/curated/en/828661517490252879/ Compendium-of-international-and-national-legal-frameworks-onfemale-genital-mutilation [reviewed 2020.08.19].

14. Vyklyky dlia ukrainskoho zakonodavstva, poviazani z ratyfikatsiieiu Konventsii Rady Yevropy pro zapobihannia nasylstvu shchodo zhinok ta domashnomu nasylstvu ta borotbu z tsymy yavyshchamy [Challenges for Ukrainian legislation related to the ratification of the Council of Europe Convention on Preventing and Combating Violence against Women and Domestic Violence]. Available from: http://radaprogram.org/publications/ vyklyky-dlya-ukrayinskogo-zakonodavstva-povyazani-z-ratyfikaciyeyukonvenciyi-rady [reviewed 2020.08.19] (Ua).

15. Ruth M, Mestre i Mestre and Sara Johnsdotter. Court cases, cultural expertise, and "female genital mutilation" in Europe. 2019. Special Issue: Cultural Expertise and Socio-Legal Studies. Studies in Law, Politics, and Society 78: 95-113. Available from: https://www. researchgate.net/publication/331404949_Court_cases_cultural_ expertise_and_female_genital_mutilation_in_Europe [reviewed 2020.08.19]

16. Mytrofanov I, Lysenko I, Ryabushko M. Genital mutilation as a consequence of a criminal offense. Wiadomości Lekarskie. 2020;73(1):823-828.

17. Antypov V. Kryminalnyi kodeks Ukrainy v konteksti mizhnarodnoho prava ta praktyky Yevropeiskoho sudu z prav liudyny : pravovi normy, sudova praktyka, naukovo-praktychnyi komentar [Criminal Code of Ukraine in the context of international law and practice of the European Court of Human Rights: legal norms, case law, scientific and practical commentary]. Kharkiv: Pravo; 2019. 1200 p. (Ua).

\section{ORCID and contributionship:}

Volodymyr I. Tiutiuhin: 0000-0002-1174-3075

Anton O. Baida: 0000-0002-5532-899X

Viktoriia V. Bazeliuk: 0000-0001-5223-8633

\section{Conflict of interest:}

The Authors declare no conflict of interest.

\section{CORRESPONDING AUTHOR Volodymyr I. Tiutiuhin \\ Department of criminal law, Yaroslav Mudriy National Law University Pushkinskaya str., 77, 61024 Kharkiv, Ukraine tel: +380956500941; +380677073317 e-mail: tvil1947@gmail.com}

Received: 30.08 .2020

Accepted: 26.11 .2020

A - Work concept and design, B - Data collection and analysis, $\mathbf{C}$ - Responsibility for statistical analysis, D-Writing the article, $\mathbf{E}$-Critical review, $\mathbf{F}$ - Final approval of the article 